\title{
TRANSFORMASI PENDIDIKAN UNTUK MENGHADAPI GLOBALISASI
}

\author{
ANITA RINAWATI \\ Universitas Muhammadiyah Purworejo \\ Purworejo, Indonesia \\ e-mail: anita_rinawati@yahoo.co.id
}

\begin{abstract}
ABSTRAK
Globalisasi membawa dampak perubahan yang sangat signifikan terutama terhadap perubahan dari perilaku setiap individu. Kaitan antara globalisasi dan pendidikan terletak pada lahirnya suatu masyarakat baru yang ditandai dengan "knowledge-basedsociety" yang merupakan dasar dari globalisasi ekonomi dan politik yang terus-menerus berubah dan memerlukan sikap reflektif dari manusia yaitu kemampuan untuk merenungkan mengenai kehidupannya berdasarkan rasio. Untuk itu pendidikan sangat penting dalam mewujudkan masyarakat masa depan yang berdasarkan ilmu pengetahuan.

Peran dari transformasi pendidikan agar dapat menghasilkan manusia yang siap untuk menghadapi tantangan global. Salah satu cara menghadapi globalisasi dengan langkahlangkah transformasi pendidikan dan peningkatan peran guru yang dapat menyesuaikan dengan kondisi saat ini. Hal ini agar pendidikan yang ada tidak tertinggal dan dapat terus bertahan untuk menghadapi dampak negatif dari globalisasi.
\end{abstract}

\section{Kata Kunci: Globalisasi,Transformasi Pendidikan}

\section{ABSTRACT}

The impact of globalization brings significant changes, especially to the changes of the behavior of each individual. The link between globalization and education lies at the birth of a new society marked by "knowledge-basedsociety" which is the basis of economic and political globalization is constantly changing and requires a reflective attitude of humans is the ability to reflect on his life based on the ratio. To that education is very important in realizing the future society which is based on science.

The role of the transformation of education in order to produce a human who is ready to face the global challenges. One way to face globalization with measures of education transformation and the increased role of teacher who can adjust to current conditions. This is so that there is not left behind education and can continue to survive to face the negative effects of globalization.

Keywords: Globalization, Education Transformation

\section{PENDAHULUAN}

Globalisasi saat ini semakin dirasakan oleh setiap individu yang mendorong adanya perubahan dalam pola perilaku. Globalisasi merupakan salah satu faktor pendorong adanya perubahan dalam struktur, nilai, norma dan tingkah laku manusia. Menurut H.A.R.Tilaar (2002), perubahan yang terjadi di masyarakat disebabkan oleh tiga faktor utama, yaitu; kebutuhan akan demokratisasi, kemajuan ilmu pengetahuan dan globalisasi. Adanya perubahan yang begitu pesat dalam proses globalisasi semakin menuntut manusia untuk lebih berkualitas dalam hidup dan agar mampu bersaing. Kemajuan teknologi dan semakin mudahnya akses antar negara dalam hal modal, investasi, juga sumber daya manusia merupakan dampak adanya globalisasi. Hal ini menciptakan persaingan yang semakin ketat dalam setiap lini kehidupan, sehingga diperlukan manusia yang mampu bertahan dan berkualitas. Untuk 
mewujudkan manusia yang berkualitas salah satunya dapat melalui pendidikan.

Kaitan antara globalisasi dan pendidikan terletak pada lahirnya suatu masyarakat baru yaitu yang ditandai dengan "knowledge-basedsociety" yang merupakan dasar dari globalisasi ekonomi dan politik yang terus-menerus berubah dan memerlukan sikap reflektif dari manusia yaitu kemampuan untuk merenungkan mengenai kehidupannya berdasarkan rasio. Untuk itu pendidikan sangat penting dalam mewujudkan masyarakat masa depan yang berdasarkan ilmu pengetahuan.

Pendidikan bukan hanya sekedar hak azasi manusia, tetapi juga sebagai alat strategis untuk membangun masyarakat. Pendidikan sudah diyakini dapat melakukan perubahan kearah yang lebih baik. Melalui pendidikan maka akan dapat dihasilkan manusia yang berkualitas dan mampu bersosialisasi dengan masyarakat. Untuk mendapatkan pendidikan yang berkualitas sangat diperlukan sarana prasana, guru, dan perangkat pembelajaran yang mendukung proses pembelajaran. Selain itu juga kerjasama dari semua pihak baik sekolah, masyarakat dan pemerintah. Akan tetapi kenyataan yang ada saat ini pendidikan di Indonesia masih belum memuaskan. Terbukti dengan adanya permasalahan di bidang pendidikan yang masih sangat kompleks. Hasil dari pendidikan itu sendiri juga masih belum dapat menjawab tantangan yang ada. Masih carut marutnya penerapan kurikulum di sekolah serta masih banyaknya lulusan yang tidak mampu masuk dalam dunia kerja sesuai dengan latar belakang pendidikannya.

Apabila masih tingginya tingkat pengangguran di Indonesia maka akan berakibat menurunnya kualitas hidup dari manusia, sehingga tidak mampu bersaing dan bertahan dalam menghadapi tantangan global. Berdasarkan data dari BPS/Badan Pusat Statistik tahun 2014 untuk saat ini jumlah tenaga kerja berdasarkan tingkat pendidikannya dapat dilihat sebagai berikut:

Tabel 1 Pengangguran Terbuka Menurut Pendidikan Tertinggi yang Ditamatkan 2012 2014

\begin{tabular}{clrrr}
\hline NO & \multicolumn{1}{c}{ Pendidikan Terakhir } & \multicolumn{1}{c}{$\mathbf{2 0 1 2}$} & \multicolumn{1}{c}{$\mathbf{2 0 1 3}$} & \multicolumn{1}{c}{$\mathbf{2 0 1 4}$} \\
\hline $\mathbf{1}$ & Tidak/belum pernah sekolah & 85374 & 81432 & 74898 \\
$\mathbf{2}$ & Belum/tidak tamat SD & 512041 & 489152 & 389550 \\
$\mathbf{3}$ & SD & 1452047 & 1347555 & 1229652 \\
$\mathbf{4}$ & SLTP & 1714776 & 1689643 & 1566838 \\
$\mathbf{5}$ & SLTA / Umum & 1867755 & 1925660 & 1962786 \\
$\mathbf{6}$ & SLTA Kejuruan & 1067009 & 1258201 & 1332521 \\
$\mathbf{7}$ & Diploma I,II,III/Akademi & 200028 & 185103 & 193517 \\
$\mathbf{8}$ & Universitas & 445836 & 434185 & 495143 \\
& Total & 7344866 & 7410931 & 7244905 \\
\hline
\end{tabular}

(Sumber: BPS, data diolah)

Fakta di atas sangat urgent untuk disikapi sekaligus dijadikan bahan introspeksi bagi pribadi, masyarakat dan negara. Tuntutan dari dunia kerja untuk SDM(Sumber Daya Manusia) saat ini juga semakin tinggi. Akibat adanya persaingan yang ketat, dan melimpahnya penawaran tenaga kerja sedangkan lapangan pekerjaan semakin sempit. Menimbulkan munculnya banyak persoalan sosial di tengah masyarakat, seperti kemiskinan, kejahatan, yang lebih mendasar lagi munculnya sikap tidak perduli dengan sesama anggota masyarakat.

Pada dunia pendidikan di Indonesia saat ini juga masih belum jelas arah tujuannya baik jangka pendek maupun panjang. Hal ini dapat ditunjukkan melalui beberapa persoalan 
seperti tidak adanya visi pendidikan; lemahnya itikad pemerintah dalam mewujudkan alokasi anggaran yang hanya $20 \%$ untuk pendidikan. Jelas menunjukkan ketidakberpihakan pemerintah pada pendidikan; program peningkatan kualitas (misalnya melalui sertifikasi guru) masih bersifat tambal sulam tanpa perencanaan yang jelas dan lebih terkesan 'supaya ada proyek'. Selain itu gonjang-ganjing ganti menteri ganti kebijakan (kurikulum) pun perlu dicermati dimana proses sosialisasi kebijakan yang terpaku pada jenjang birokrasi makin memperkeruh kualitas pendidikan Indonesia.

Kebijakan yang disusun oleh lembaga penyusun standar nasional pendidikan terkesan instan dan membingungkan dalam hal aplikasi di lapangan. Belum adanya kesiapan guru dalam menyusun dan menerjemahkan kurikulum mengakibatkan persoalan baru dalam kurikulum nasional versi terbaru, seperti muatan operasional (lingkungan, teknologi, globalisasi, kesehatan, ekonomi, dll), pengembangan diri (leadership dan life skill) serta muatan lokal (pengembangan potensi daerah) hanya menjadi slogan saja dan tidak tercermin dalam silabus pengajaran.

Berdasarkan persoalan tersebut dapat dilihat bahwa pengaruh globalisasi yang merubah perilaku, nilai, dan norma dimasyarakat. Jika tidak disikapi dengan serius maka akan semakin menciptakan manusia yang tertindas. Salah satu cara untuk menghadapinya dengan melalui pendidikan. Akan tetapi melihat kondisi pendidikan di Indonesia, maka diperlukan adanya transformasi pendidikan yang mampu membawa masyarakat untuk menjadi lebih berkualitas dan mampu menjawab tantangan global. Berdasarkan uraian tersebut maka akan dikupas lebih mendalam tentang bagaimana peran transformasi pendidikan dalam menghadapi globalisasi?

\section{PEMBAHASAN}

Sudah tidak asing lagi bahwa pendidikan selain transfer of knowledge (transfer ilmu), juga berfungsi sebagai transfer of value (transfer nilai). Nilai di sini juga dimaksudkan pendidikan sebagai transfer untuk perubahan sosial. Lebih sempit pendidikan formal berfungsi sebagai proses pembaharuan sosial. Pendidikan merupakan investasi manusiawi (human investment) yang sangat penting dalam kemajuan suatu masyarakat. Oleh karena itu banyak bangsa-bangsa di dunia ini meletakkan pendidikan sebagai faktor strategis dalam merespon berbagai kemajuan.

Untuk itulah pendidikan tentu saja memegang peranan yang sangat penting dalam menghadapi perubahan di era global ini. Pendidikan akan memberikan arah yang jelas tentang bagaimana menyikapi perubahan. Perubahan akan terasa dapat dilalui dengan baik dan dijadikan sebagai landasan dalam mewujudkan pembangunan masyarakat Indonesia seutuhnya apabila pendidikan menjadi pilar utama dalam perubahan itu. Dengan demikian pendidikan dapat sebagai alat tranformasi, untuk itu seharusnya dan sewajarnya perhatian terhadap pendidikan lebih tinggi dibandingkan bidang-bidang lain, karena bidang-bidang yang lain akan berkembang dengan sendirinya jika pendidikan sudah terlebih dahulu baik. Akan tetapi kenyataan yang ada pendidikan di Indonesia secara faktual masih dinilai tertinggal dibandingkan dengan negara-negara lain.

Indonesia merupakan negara yang mutu pendidikannya masih rendah jika dibandingkan dengan negaranegara lain bahkan sesama anggota negara ASEAN pun kualitas SDM bangsa Indonesia masuk dalam peringkat yang paling rendah. Hal ini terjadi karena pendidikan di Indonesia belum dapat berfungsi secara maksimal. Oleh karena itu diperlukan adanya transformasi pendidikan agar mampu melahirkan generasi yang memiliki keunggulan dalam berbagai bidang supaya bangsa Indonesia dapat 
bersaing dengan bangsa lain dan agar tidak semakin tertinggal karena arus global yang berjalan cepat. Berdasarkan Survey United Nations Educational, Scientific and Cultural Organization (UNESCO), terhadap kualitas pendidikan di Negara-negara berkembang di Asia Pacific, Indonesia menempati peringkat 10 dari 14 negara. Sedangkan untuk kualitas para guru, kualitasnya berada pada level 14 dari 14 negara berkembang.

Menurut Hilda Taba dalam Mahmud Arif $(2008,18)$ secara luas pendidikan adalah bagian dari "rekayasa sosial" yang secara sengaja dan sistematis berlangsung dalam sebuah kurun waktu tertentu sehingga ia tidak hanya berarti interaksi tatap muka (face to face) antara guru dan murid dalam lingkungan kelas. Pendidikan merupakan inti dari proses "pembudayaan" yang berlangsung di tengah-tengah kehidupan masyarakat, di mana terkandung di dalamnya proses pengembangan potensi, pewarisan budaya, dan perpaduan antar keduanya.

Dapat dipahami bahwa melalui pendidikan akan dapat mempengaruhi perilaku keseharian masyarakat yang sudah terkena dampak dari globalisasi. Bagaimana bertindak dan bersikap dalam lingkungannya, sehingga dapat sejajar dengan bangsa lain, dalam hal ini dapat melalui transformasi pendidikan.

\section{Konsep Dasar Transformasi Pendidikan}

Transformasi dalam ensiklopedi umum merupakan istilah ilmu eksakta yang kemudian diintrodusir ke dalam ilmu sosial dan humaniora, yang memiliki maksud perubahan bentuk dan secara lebih rinci memiliki arti perubahan fisik maupun nonfisik (bentuk, rupa, sifat, dan sebagainya). Selain itu pengertian transformasi menurut bahasa dalam ensiklopedi nasional Indonesia memiliki pengertian, perubahan menyeluruh dalam bentuk, rupa, sifat, watak, dan sebagainya, dalam hubungan timbal balik sebagai individu-individu maupun kelompokkelompok.

Pendapat Mezirow (2006:6) dalam Arif Unwanullah menjelaskan konsep transformasi sebagai berikut: ... the concept of transformative learning which he defines as "the process by which we transform our takenforgranted frames of reference"). Kemudian lebih lanjut dikatakan bahwa $\mathrm{He}$ asserts that transformation takes place through a process of critical reflection that is facilitated by open dialogue in a safe setting. In conjunction with this reflection and dialogue, Transformation Theory's focus is on how we learn to negotiate and act on our own purposes, values, feelings, and meanings rather than those we have uncritically assimilated from others Mezirow, (2000: 6-7).

Yang berarti bahwa konsep pembelajaran transformatif didefinisikan sebagai proses di mana kita mengubah bingkai acuan. Dia menegaskan bahwa transformasi berlangsung melalui proses refleksi kritis yang difasilitasi oleh dialog terbuka dalam suasana yang aman. Dalam hubungannya dengan refleksi dan dialog maka fokus teori transformasi adalah pada bagaimana kita belajar untuk bernegosiasi dan bertindak pada tujuan kita sendiri, nilai-nilai, perasaan, dan makna yang kita miliki secara kritis yang diasimilasikan dari dan pada orang lain.

Sementara dalam penjelasan Agus Salim (2002), transformasi adalah suatu proses penciptaan suatu hal yang baru (somethig new) yang dihasilkan oleh ilmu pengetahuan dan teknologi. Agus menjelaskan yang berubah adalah asek budaya yang sifatnya material sedangkan sifatnya immaterial sulit sekali diadakan perubahan. Membahas istilah transformasi jika tanpa dikaitkan dengan sesuatu yang lain menurut Ryadi Gunawan (1993) dalam Mashur Amin, merupakan upaya pengalihan dari sebuah bentuk kepada bentuk yang lebih mapan. Sebagai sebuah proses, transformasi merupakan tahapan, atau 
titik balik yang cepat bagi sebuah makna perubahan.

Munculnya konsep transformasi juga tidak lepas dengan hadirnya tokoh Karl Marx dan Max Weber. Bagi Marx, transformasi masyarakat dibayangkan melalui proses dialektika transformasi kontinyu dengan hadirnya pertentangan kelas yang memperebutkan penguasaan berbagai alat reproduksi dan saat mencapai puncak dialektika akan tercipta "masyarakat yang tak berkelas". Gagasan ini bersumber dari filsafat dialektikanya Hegel yang mengajarkan tentang siklus tesis dan antitesis.

Sementara bagi Weber, bayangan transformasi itu tidaklah lewat suatu proses dialektika linear sebagaimana pikiran Marx, namun proses transformasi dan perubahan itu melalui proses evolusioner yang mana berbagai unsurnya saling berpengaruh atau saling mempengaruhi dalam sebuah tipe ideal masyarakat. Dari pemaparan tersebut, sebenarnya pengertian transformasi itu dikenakan pada sejumlah objek sehingga sebagai konsep, sering merupakan sebuah diskusi yang panjang. Untuk itulah dengan melalui tansformasi diharapkan ada proses perubahan yang lebih baik bagi tiap individu, dalam hal ini transformasi melalui jalur pendidikan.

Pendidikan untuk transformasi seperti dikutip dalam Naif (2009) merupakan mainstream aliran pendidikan berhaluan Freirean (Paulo Freire). Teori yang dikemukakan oleh Paulo Freire sering menjadi sebuah wacana dialogis untuk menyelesaikan kebekuan dalam pendidikan. Salah satu teorinya dalam pendidikan yang paling terkenal adalah bahwa pendidikan untuk memanusiakan manusia (humanisasi). Teori ini lebih condong ke arah filosofi eksistensialisme yang berusaha menggagas konsep manusia dan seluk beluk persoalan yang melingkupinya. Aliran pendidikan ini menggugat kemapanan pendidikan yang dianggap stagnan tanpa memberikan arti dan perubahan yang signifikan bagi realitas yang dihadapi manusia.

Berkaitan dengan pendidikan bagi anak manusia dalam menjalani proses untuk "menjadi" manusia ini, tentu pendidikan tidak bisa dilepaskan dari persoalan sosial yang sedang terjadi. Pendidikan yang hanya membekali peserta didik dengan pengetahuan yang tidak mencerahkan terkait kehidupan sosial atau justru malah membuat kemanusiaan tertindas secara sosial semestinya ditinggalkan. Inilah hal penting dari pendidikan sebagai proses yang membebaskan. Sebuah proses pendidikan yang meninggalkan cara dan aktivitas yang sesungguhnya justru dehumanisasi menuju cara dan aktivitas pendidikan yang penuh dengan proses humanisasi.

Dengan menjadikan pendidikan sebagai cara dan aktivitas yang penuh dengan proses humanisasi, hal ini sesungguhnya telah menjadikan pendidikan sebagai sebuah proses transformasi sosial menuju perubahan ke arah kemajuan di tengah masyarakat. Proses pendidikan ini ditandai dengan adanya peralihan situasi dari: teologi tradisional menuju teologi pembebasan, proses yang tidak mengenal dialog menuju hubungan yang penuh dialogis, kehidupan masyarakat yang tertutup menuju kehidupan masyarakat yang terbuka, dan masyarakat yang jauh dari pengetahuan menuju masyarakat yang sadar serta membutuhkan ilmu pengetahuan. Dengan demikian, pendidikan merupakan suatu sarana untuk memproduksi kesadaran dalam rangka mengembalikan manusia kepada hakikat kemanusiaannya. Selain itu melalui pendidikan sebagai kunci keberhasilan dalam menghadapi globalisasi.

Berkaitan dengan pendidikan sebagai sarana untuk memproduksi kesadaran untuk mengembalikan manusia kepada hakikat kemanusiaannya, maka pendidikan harus bisa berperan membangkitkan kesadaran kritis para peserta didik. Ini adalah sebagai prasyarat penting menuju 
pembebasan dalam era global dimana yang tidak dapat bersaing akan semakin tertindas. Terkait dengan masalah ini, salah satu tugas penting pendidikan adalah melakukan refleksi kritis terhadap sistem dan ideologi yang dominan dan menguasai masyarakat pada umumnya. Refleksi kritis ini dilakukan dalam rangka untuk memikirkan sistem alternatif ke arah perubahan sosial menuju kehidupan masyarakat yang berkeadilan.

Ketika Ki Hajar Dewantara menyatakan anak-anak Indonesia harus dididik dalam suatu sistem pendidikan yang berakar pada kebudayaan sendiri, bukan pendidikan yang berakar pada kebudayaan Belanda, maka pandangan ini sungguh merupakan suatu ledakan politik yang dahsyat saat itu. Jadi sebenarnya Indonesia sudah memiliki tokoh yang peduli dengan pendidikan, dimana tidak mengacu pada pendidikan barat yang belum tentu cocok untuk Indonesia. Ki Hajar Dewantara dengan Tut Wuri Handayani yang mendasarkan pendidikan dari kebudayaan Indonesia, apabila dijalankan maka akan dapat membentuk manusia yang arif, bijaksana dan mampu membentuk masyarakat yang jauh dari budaya barat. Akhirnya akan dapat mewujudkan masyarakat yang tidak mudah goyah dengan adanya dampak negatif dari globalisasi.

Kebijakan pendidikan yang selama ini terjadi lebih banyak diwarnai oleh kepentingan politik. Kebijakan pendidikan yang ada bersifat tambal sulam dan bersifat proyek. Adanya anggapan ganti menteri ganti kebijakan yang dituangkan dalam pergantian kurikulum merupakan sindirian, betapa kebijakan pendidikan di negeri ini tidak pernah dapat menjadi acuan bagi pengembangan pendidikan dan proses pembelajaran. Berbeda dengan kebijakan pendidikan di negara-negara maju yang sifatnya lebih permanen dan benar-benar mencerminkan kebutuhan pengembangan pendidikan, kebijakan pendidikan di Indonesia sifatnya sementara, parsial dan tidak berkelanjutan. Kebijakan pendidikan di negara-negara maju lebih mengarah pada kebijakan pendidikan transformatif yang mampu merespon tantangan ke depan, sementara kebijakan pendidikan di Indonesia lebih banyak mengarah pada kebijakan pendidikan incremental yang ditujukan untuk menjawab persoalan. Sehingga kebijakan pendidikan tidak responsif terhadap tantangan. Yang terjadi kemudian adalah kebijakan pendidikan selalu kedodoran apabila dihadapkan dengan era global dan untuk menjawab tantangan masa depan. Oleh karena itu, kebijakan pendidikan yang dibangun ke depan haruslah bebas dari kepentingan politik, kebijakan yang transformatif untuk merespon tantangan dan berjangka panjang.

\section{Langkah-Langkah Mewujudkan Transformasi Pendidikan}

Pengelolaan pendidikan untuk kepentingan bersama dapat menjadi pengurai benang kusut persoalan masyarakat Indonesia dan menjawab tantangan global saat ini. Berdasarkan Peraturan Menteri Pendidikan Nasional RI No. 22, 23 dan 24 Tahun 2006, Sekolah telah diberi kewenangan untuk menyusun kurikulum dengan melibatkan komite sekolah dan masyarakat. Berbagai upaya menjalin kerjasama baik berupa pelatihan, lokakarya, pembentukan komunitas guru, penelitian bersama dan bentukbentuk lain yang mengarah pada pertukaran informasi serta inovasi diperlukan untuk meningkatkan kemampuan guru dalam memahami model, metode serta muatan dalam penyusunan kurikulum. Saling menghargai peran diantara pengelola sekolah dengan masyarakat sekitar sekolah, tokoh masyarakat, ahli pendidikan dan birokrasi diharapkan dapat mempercepat proses peningkatan mutu pendidikan.

Adapun langkah-langkah dalam mewujudkan transformasi pendidikan dapat diuraikan sebagai berikut: Pertama, dari segi kurikulum. Pemerintah perlu mengkaji ulang persoalan konseptual fundamental pada 
kurikulum. Untuk saat ini yang sedang banyak dibahas adalah Kurikulum 2013 meskipun sudah kembali lagi ke kurikulum KTSP. Perlu dikaji kembali pada Kurikulum 2013 terutama konsep Kompetensi Inti (spiritual, sikap sosial, pengetahuan dan keterampilan) dan Kompetensi Dasar. Deskripsi kompetensi inti hendaknya mengintegrasikan seluruh domain berpengetahuan dengan mengorientasikan Kurikulum Inti pada nilai-nilai Pancasila yang dinyatakan di setiap jenjang pendidikan. Penentuan Kompetensi Dasar ini disertai dengan indikator kompetensi dasar. Desain silabus diserahkan pada Pemerintah Daerah, Rencana Pelaksanaan Pembelajaran (RPP) didesain oleh guru di satuan pendidikan. Pemerintah daerah mengembangkan buku ajar berdasarkan Kompetensi Dasar dan Silabus sehingga semangat keragaman dan kebhinekaan tetap terjaga. Pendidikan agama dilaksanakan secara mandiri, tidak digabungkan dengan pendidikan budi pekerti. Isi pelajaran agama hendaknya berupa ajaran dan sikap-sikap religius yang terarah pada nilai-nilai kesalehan sosial yang bersifat inklusif. Sementara pendidikan Budi Pekerti yang bersifat lintas agama/iman/keyakinan penting untuk dikembangkan di sekolah dalam rangka memperkaya pengalaman keragaman siswa. Dalam konteks pembelajaran pemerintah sebaiknya mengembalikan pembelajaran TIK dalam pembelajaran di sekolah sebagai bagian dari pengembangan kemampuan literasi media anak-anak Indonesia untuk menjawab tantangan global. Dalam kaitannya dengan kebijakan pendidikan, Pemerintah selayaknya mengkaji ulang payung hukum yang menjadi dasar pelaksanaan Kurikulum 2013 dan mengadakan sinkronisasi kebijakan Kurikulum sesuai dengan peraturan perundang-undangan yang berlaku.

Kurikulum harus berbasis pada kekuatan keunggulan lokal wilayah bukan terpusat yang mengakibatkan peserta didik mengalami teralienasi dari keunggulan wilayahnya. Pendidikan harus terhubung dengan lingkungan sosialnya termasuk pilihan-pilihan pekerjaan peserta didik kedepan harus diupayakan dan benar-benar disiapkan oleh pemerintah tempat-tempat pekerjaan dimana kelak peserta didik akan mengembangkan kreatifitasnya tersebut. Jadi, peserta didik diberikan kebebasan untuk memilih keahlianya yang kelak akan menjadi mata pencaharian hidupnya. Dalam kaitannya dengan kurikulum pemerintah tidak boleh lepas tangan membiarkan para lulusan peserta didik segala tingkat menjadi pengangguran total. Ini adalah blunder dalam sebuah sistem pendidikan. Jadi, pemerintah selain menyiapkan tempat pendidikan juga mempersiapkan pekerjaan bagi para peserta didik sesuai bakat dan minatnya.

Kedua, Transformasi pendidikan dari dilihat dari segi tujuan pendidikan. Yang paling mendasar adalah merubah tujuan pendidikan dari siap pakai menjadi siap memakai, dari berpikir pasif menunggu menjadi pribadi yang pro aktif positif. Dari terbiasa diatur menjadi mengatur, dari kuli menjadi 'setidaknya' mandor. Sehingga kita bisa menjadi tuan di negeri kita sendiri, bukan menjadi kuli bangsa lain di negeri kita sendiri seperti apa yang kita lihat sekarang. Adanya perubahan yang lebih bersifat aktif bagi setiap individu inilah yang akan menjawab tantangan di era global dan dapat bersaing sehingga tidak tertindas.

Ketiga mempersiapkan PSB ( Pusat Sumber Belajar ) pada setiap kota.Hal ini memerlukan pendanaan yang tidak sedikit akan tetapi akan efektif untuk mempercepat pelaksanaan transformasi pendidikan. Fungsi dari PSB misalnya untuk penggandaan materi bahan ajar dan mengadakan pelengkapan sarana pendidikan, sosialisasi kebijakan, serta pelatihan kepada setiap guru dari lembaga pendidikan yang ada di setiap kota. Penggunaan PSB ini dilakukan secara bergilir pemakaiannya diantara sekolah yang ada sesuai dengan jenjangnya. Kita pun telah memiliki 
modal solidaritas dan model pelayanan pendidikan yang telah dilakukan selama ini oleh masyarakat. Itulah yang harus diperkuat, diperbesar dan diperluas kemampuan pelayanannya melalui kerjasama. Selain langkah-langkah tersebut di atas peran penting dari Guru juga sangat berpengaruh dalam melaksanakan transformasi pendidikan untuk menghadapi tantangan global.

\section{Peran Guru dalam Transformasi Pendidikan}

Untuk mewujudkan manusia yang mampu menjawab tantangan global tentu peran guru sangatlah penting. Guru merupakan sosok penting dalam pendidikan. Pendidikan dimulai ketika siswa mengenyam pendidikan di bangku sekolah, hal ini terus berlanjut sampai dewasa. Guru dalam pendidikan sebagai ujung tombak suksesnya pendidikan. Giroux (2008) dalam Ridwan berpendapat bahwa cara kita dalam mendefinisikan peranan guru di masyarakat menentukan cara di mana kita mengonstruksi tatanan masyarakat. Kita mesti memahami kembali peranan para guru sebagai intelektual transformatif dan terlibat (engaged and transformative intellectuals). Ini berarti kita mencoba memandang guru sebagai profesional yang mampu dan mau merefleksikan prinsip-prinsip ideologis yang menjadi pandu bagi praksis mereka, yang menghubungkan teori pedagogik dengan persoalan sosial yang lebih luas, melatih kekuatan yang mereka miliki untuk menguasai kondisi pekerjaan mereka. Dengan cara ini, guru mengembangkan suatu visi pembangunan tata masyarakat baru, yaitu, sebuah visi tentang kehidupan yang lebih baik dan manusiawi melalui pendidikan dan pengajaran yang mereka berikan. Pandangan ini lebih memposisikan peranan guru sebagai pelaku perubahan dalam masyarakat. Pandangan guru tentang masyarakat inilah yang menentukan bagaimana guru melaksanakan tugasnya sebagai pelaku perubahan.

Agar menjadi pelaku perubahan, guru tidak dapat melestarikan pandangan dan paradigma pendidikan yang sifatnya daur ulang dan atau sekedar meneruskan pandangan yang dibawa oleh pasar. Demikian juga, guru tidak bisa sekedar memberikan ketrampilan bagi siswa agar memiliki sikap kritis terhadap situasi sosial di mana mereka tinggal. Di sini, pandangan guru tentang siapa individu siswa menjadi penting, sebab akan mempengaruhi bagaimana ia bekerja sebagai pelaku perubahan. Individu adalah mahluk yang bebas dan memiliki kemampuan untuk terlibat dalam menentukan dirinya, sehingga dengan demikian mereka dapat menjadi pelaku sejarah.

Guru mesti berani mulai mengembangkan paradigma baru yang inspirasi dasarnya adalah nilai-nilai demokratis dan memiliki prinsip dasar pada partisipasi tiap individu dalam pengaturan tata kehidupan masyarakat. Hanya melalui inspirasi demokratis inilah terdapat jaminan bahwa setiap warga dalam masyarakat memiliki hak dan persamaan dalam menata hubungan sosial, politik, dan ekonomi antar mereka. Keterlibatan dan partisipasi aktif tiap individu dalam berdemokrasi memungkinkan terwujudnya keadilan, dilindunginya hak-hak kelompok minoritas dan jaminan bagi mereka yang kurang beruntung agar mereka dapat tetap terlibat aktif dalam kehidupan masyarakat. Hal inilah yang menjadi kekuatan dan tameng terhadap dampak adanya globalisasi. Sehingga tiap individu akan mampu dan bertahan dalam kondisi yang sangat ketat dalam persaingan. Dalam hal ini peran guru dalam melihat siswa secara objektif sangat diperlukan agar dalam proses belajar mengajar prinsip keadilan dapat berjalan.

Tanpa ada keadilan dan persamaan dalam mengenyam pendidikan, lembaga pendidikan hanya akan melestarikan ketimpangan dan mengelompokkan orang-orang miskin menjadi bagian pasif dan beban bagi masyarakat. Sekali lagi, gagasan guru tentang individu sangatlah penting, 
sebab pandangan yang tidak kuat terhadap individu justru bisa memandulkan kinerja tranformatif guru itu sendiri. Contoh, kalau guru menganggap bahwa orang miskin itu hanya pantas mengenyam pendidikan SMK, dia akan mengarahkan anak-anak orang miskin itu ke SMK, agar segera dapat memperoleh pekerjaan, tanpa memperdulikan apakah pekerjaan itu merupakan pekerjaan bermakna, atau tanpa peduli bahwa setiap individu berhak menggantungkan cita-citanya setinggi langit tanpa dibatasi oleh keinginan terbatas sang guru.

Proses transformasi pendidikan pada ranah guru yang perlu dibenahi mencakup penataan dan pemerataan guru, mutu dan kesejahteraan guru. Penataan dan pemerataan guru ini sangat penting karena konfigurasi keberadaan guru yang masih amburadul. Dalam konteks penataan dan pemerataan guru, perlu diadakan payung hukum yang dapat lebih menjamin implementasi kebijakan. Selama ini penataan dan pemerataan guru hanya didasarkan pada surat keputusan bersama beberapa menteri, di mana payung hukum seperti ini tidak cukup kuat sebagai payung hukum implementasi kebijakan pendidikan. Oleh karena itu, ke depan diperlukan payung hukum yang lebih tinggi berupa Peraturan Pemerintah (PP). Dalam PP ini hendaknya termuat pemetaan pendidikan meliputi guru dan rombel sekolah (bagi daerah yang belum melakukan pemetaan pendidikan), perhitungan kebutuhan guru yang akan diajukan pemerintah daerah ke pemerintah pusat untuk formasi CPNS guru dilakukan setelah penataan dan pemerataan guru berhasil dilakukan. Pemerataan bukan hanya berorientasi pada kuantitas tetapi juga kualitas guru. Termasuk juga pemerataan guru yang bermutu ke sekolah yang dibawah standar. Ada target waktu yang jelas tercapainya target penataan dan pemerataan guru.

Selain itu peningkatan mutu dan perbaikan kesejahteraan guru harus menjadi perhatian serius. Untuk itu pemerintah perlu memperbaiki regulasi pengelolaan guru, perbaikan regulasi distribusi guru, perbaikan regulasi linieritas dan legalitas kelembagaan penghasil guru (LPTK), meminimalisasi mismatch antara bidang studi dan area distribusi, serta penataan regulasi yang mengatur mekanisme dan prosedur pengendalian PKG berbasis management information system.

Perlunya penghargaan yang besar terhadap guru yang baik dan berdedikasi, baik oleh pemerintah maupun masyarakat, baik moril maupun materiil. Kalau perlu fasilitas terbaik ada pada guru yang profesional, memiliki disiplin tinggi serta berakhlaq mulia. Karena guru-guru yang baik inilah yang akan mencetak putra bangsa yang terbaik Kesadaran ini benar-benar harus disosialisasikan kepada masyarakat, sehingga muncul masyarakat yang menghargai guru serta haus akan ilmu yang bermanfaat. Konsekuensi dari hal di atas adalah putra-putri bangsa terbaiklah yang akan memperebutkan profesi keguruan, dan seleksipun dapat dilakukan dengan ketat dengan sistem yang transparan. Di Jepang, peran dan profesionalitas guru sangat dikedepankan. Guru TK di Jepang paling tidak memiliki tingkat pendidikan S2 ataupun professor.

Pemberian bekal pelajaran tentang leadership yang nantinya akan diteruskan kepada siswa. Hal ini sangat perlu bagi guru karena dimuka kelas sosok guru merupakan seorang pemimpin. Secarut marut pendidikan di Indonesia, guru merupakan ujung tombak pembelajaran di kelas yang langsung berinteraksi dengan murid. Guru juga harus dibekali dengan ilmu tentang kewirausahaan atau entrepreneur. Entrepreneur yang dimaksudkan tidak hanya mengenai business entrepreneur tetapi juga mengenai social entrepreneur dengan harapan dapat mempercepat proses transformasi yang akan dapat diterapkan dalam masyarakat. Guru sebisa mungkin menggunakan metode mengajar yang inovatif dan kreatif, dari hanya mendengar guru berbicara 
dengan membaca buku paket menjadi kegiatan belajar mengajar menggunakan modul yang dapat dilakukan dan didiskusikan. Pendekatan utamanya adalah "Learn by doing" sehingga dapat lebih dimengerti dan bermanfaat bagi murid. Pemanfaatan teknologi Informasi juga harus ditingkatkan dalam rangka proses belajar mengajar maupun dalam pengelolaan database informasi sekolah.

Segera mempersiapkan dan mengadakan pendidikan tinggi yang lebih bermutu terutama untuk Perguruan Tinggi yang akan mencetak guru. Titik berat pendidikannya adalah Leadership dan Entrepreneurship (juga termasuk social entrepreneurship), pembentukan karakter, penguasaan wawasan ragam ilmu, manajemen sekolah maupun ilmu pedagogik, memiliki pribadi yang terbuka sadar atas lingkungan, mudah bergaul baik dengan guru, orang tua murid maupun masyarakat lingkungan sekola. Selain itu harus berani merubah sistem senioritas menjadi sistem profesional atau sistem orang yang terbaik dalam penentuan kepala sekolah, karena sebaik-baiknya guru tetapi bila kepala sekolah tidak disiplin akan berdampak pula bagi guru yang baik, dan yang menjadi korban adalah anak didik yang tidak terkendali.

Oleh sebab itu pendidikan sebagai transformasi pendidikan tidak dapat berhasil jika guru tidak dapat berperan sebagai agen perubahan. Transformasi pendidikan menurut Unwanullah (2012) akan dapat mewujudkan generasi penerus yang mampu mencari nafkah, mampu mengembangkan kehidupan yang bermakna, dan mampu untuk turut memuliakan kehidupan. Selain itu yang perlu disadari bersama bahwa transformasi melalui pendidikan akan terus dilakukan dan tidak memiliki ujung akhir karena persoalan di lingkungan masyarakat yang berkaitan dengan masalah sosial sebagai akibat adanya kemajuan teknologi dan globalisasi akan selalu ada selama peradaban dan kehidupan manusia itu masih ada.

\section{KESIMPULAN \\ Globalisasi merupakan suatu proses yang mengintegrasikan kehidupan global. Globalisasi sebagai salah satu pemicu adanya permasalahan sosial dan perubahan dalam masyarakat. Untuk itu perlu diwujudkan adanya transformasi pendidikan agar dapat mewujudkan masyarakat yang didasarkan pada knowledge-based-society. Peran transformasi pendidikan terhadap globalisasi dapat dilakukan dengan menggunakan langkah langkah pembaharuan di bidang pendidikan itu sendiri. Serta memberikan tempat yang layak bagi guru-guru sebagai agen perubahan dalam pendidikan. Transformasi Pendidikan diakui dapat mewujudkan masyarakat yang memahami akan pentingnya sikap saling toleran dan berperilaku baik serta siap dalam menghadapi tantangan globalisasi. Akan tetapi dalam pelaksanaannya dibutuhkan masyarakat dan pemerintahan yang serius dalam memikirkan pendidikan sebagai alat untuk mewujudkan SDM yang berkualitas.}

\section{DAFTAR PUSTAKA}

Arismunandar. Manajemen Pendidikan: Peluang dan Tantangan. Makassar: Badan Penerbit UNM, 2006.

Buchori, Mochtar. 1995. Transformasi Pendidikan. Jakarta: IKIP Muhammadiyah Jakarta Press.

H.A.R. Tilaar.2002. Perubahan Sosial dan Pendidikan: Pengantar Pedagogik Transformatif Untuk Indonesia, Jakarta: PT. Grasindo, 2002, h. 3.

Idris, Ridwan. 2013. Pendidikan sebagai Agen Perubahan Menuju masyarakat Indonesia Seutuhnya. Jurnal Lentera 
Pendidikan Vol 16. No 1. Juni 2013. Hal 62-72

Mahmud Arif.2008. Pendidikan Islam Transformatif. Yogyakarta: LkiS

Naif Adnan, 2015. Pendidikan Sebagai Transformasi Sosial http : /l naifadnan .blogspot .com/2009/08/pendidikansebagai-transformasisosial.html diunduh tanggal 22 Mei 2015.

Ryadi Gunawan.1993.Transformasi Sosial Politik: Antara Demokratisasi dan Stabilitas, dalam M. Masyhur Amin (ed) Agama, Demokrasi dan Transformasi Sosial.Yogyakarta: KPSM.

Salim, Agus. 2002. Perubahan Sosial, Sketsa Teori dan Refleksi Metodologi Kasus Indonesia.Yogyakarta: Tiara Wacana.
T.A.M. Tilaar, Peran Perguruan Tinggi di Daerah Dalam Otonomi Daerah, dalam buku Pendidikan Untuk Masyarakat Indonesia Baru: 70 Tahun Prof. Dr. H. A. R. Tilaar, M.Sc. Jakarta: Grasindo, 2002, h. 223.

Unwanullah, Arif. 2012. Transformasi Pendidikan untuk Mengatasi Konflik Masyarakat dalam Perspektif Multikultural. Jurnal Pembangunan Pendidikan: Fondasi dan Aplikasi. Vol 1, No 1, Juni 2012.

Zamroni.2002.Paradigma

Pembangunan Pendidikan Nasional Dalam Mewujudkan Peradaban Bangsa, dalam buku Pendidikan Untuk Masyarakat Indonesia Baru: 70 Tahun Prof. Dr. H.A.R. Tilaar, M.Sc. Jakarta: Grasindo. 